Jurnal Keuangan dan Perbankan, 22(4):594-605, 2018

http://jurnal.unmer.ac.id/index.php/jkdp

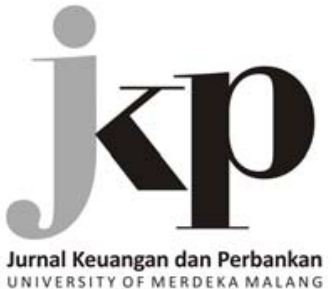

UNIVERSITY OF MERDEKA MALANG

Wiwiek Rabiatul Adawiyah (Indonesia), Bambang Agus Pramuka (Indonesia)

\title{
The Contagion Effect of Muslim Street Rallies on Stocks' Volatility: Is it a Political Risk for Investors?
}

Article history:

Received: 2018-05-01

Revised: 2018-06-27

Accepted: 2018-07-10
Wiwiek Rabiatul Adawiyah, Bambang Agus Pramuka ${ }^{2}$ ${ }^{1}$ Department of Management Faculty of Economics and Business Universitas Jenderal Soedirman

${ }^{2}$ Department of Accounting Faculty of Economics and Business Universitas Jenderal Soedirman

Jl. Prof. Dr. HR. Boejamin 708

Purwokerto, Indonesia, 53122

$\triangle$ Corresponding Author:

Wiwiek Rabiatul Adawiyah:

Tel +62 281637970

E-mail: wiwiekra@gmail.com

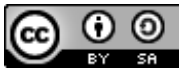

This is an open access article under the CC-BY-SA license

\begin{abstract}
Muslim street rallies refer to the super-peaceful mass street mobilizations to pressure law enforcement against a blasphemer, the Governor of Jakarta. The Event was organized by the National Movement to Safeguard the Indonesian Muslim Scholar Council's Fatwa (GNPF-MUI) on the $4^{\text {th }}$ of November (411) and $2^{\text {nd }}$ of December (212) 2016 at the capital city of Indonesia. We compares the performance of stock returns and shares trading volume on the Indonesian Stock Exchange (IDX) before and after the events. The observations were made stock performance seven days before and after the events. We found that the event had a significant influence on the abnormal return of stocks sold in the Indonesian Stock Exchange during the first event held on November $4^{\text {th }}$, but the case was different on the second event. Thus, investors do not consider the event as a political risk for portfolio investment. This study contributes to existing literature as the first to analyze the impact of the super peaceful rally on the pattern of stock price and trading volume in the Indonesian stock market.
\end{abstract}

Keywords: Market Anomalies; Muslim Street Rallies; Stock Return, Stock Trading Volume

\section{JEL Classification: G14, G32}

Citation: Pramuka, B. A., \& Adawiyah, W. R. (2018). The contagion effect of muslim street rallies on stocks' volatility: Is it a political risk for investors? Jurnal Keuangan dan Perbankan, 22(4), 594-605. https://doi.org/10.26905/ jkdp.v22i4.2123

\begin{abstract}
Abstrak
Demonstrasi turun ke jalan kaum muslimin mengacu pada aksi super damai untuk menuntut penegakan hukum terhadap Gubernur Jakarta saat itu. Acara ini diselenggarakan oleh Gerakan Nasional Pencari Fatwa Majelis Ulama Indonesia (GNPFMUI) pada tanggal 4 November (411) dan 2 Desember (212) 2016 di ibukota Indonesia. Kami membandingkan kinerja pengembalian saham dan volume perdagangan saham di Bursa Efek Indonesia (BEI) sebelum dan sesudah peristiwa aksi damai tersebut. Penelitian ini bersifat kuantitatif dengan melakukan pengamatan terhadap pergerakan saham tujuh hari sebelum dan sesudah kejadian. Kami menemukan bahwa peristiwa tersebut memiliki pengaruh yang signifikan terhadap abnormal return saham yang dijual di Bursa Efek Indonesia pada peristiwa pertama yang diadakan pada tanggal 4 November, tetapi hasilnya berbeda pada aksi turun ke jalan yang kedua. Hasil penelitian ini menunjukkan bahwa investor tidak menganggap aksi protes tersebut sebagai resiko politik bagi investasi saham di pasar modal.
\end{abstract}

Kata Kunci: Anomali Pasar; Aksi Protes ke Jalan Kaum Muslimin; Tingkat Pengembalian Saham; Volume Perdagangan Saham 


\section{The Contagion Effect of Muslim Street Rallies on Stocks' Volatility: Is it a Political Risk for Investors?}

Wiwiek Rabiatul Adawiyah \& Bambang Agus Pramuka

One recent event in Indonesia that attracts world attention was the protest against a blasphemy, involving Muslim all over districts in Indonesia. The massive 'super-peaceful 411 and 212 rally' is a 'super peaceful' gathering aiming at placing pressure on law enforcement authorities to immediately detain outspoken Jakarta Governor for allegedly conducting a blasphemy.

There were hundred thousand people from all over Indonesia attending the rally; some reported the amount of more than 3 million demonstrators. They demand the blasphemer be arrested, detained and brought to court. Muslims questioned why the police and the prosecutor's office had not detained the outspoken governor despite his status as a suspect. Despite the claim that it would be a 'superpeaceful' action, many fear that the demonstration could get out of control due to possible infiltrations of wild parties. Many offices and business centers in Jakarta were closed on those days due to fear of the rally turning into violence. It is interesting to find out whether the event raises economic sentiments among investors. This study investigates the impact of the event on stock price movement and trading volume activity.

Market anomaly has always been an interesting topic for academia. The effects of market anomalies have begun to be examined in a handful of empirical studies (Igan, Pinheiro, \& Smith, 2015; Grobys \& Heinonen, 2016; Zaremba \& Szyszka, 2016; Zaremba \& Czapkiewcz, 2017) whereby markets performance works opposite theoretical estimates. Research for anomalies provides a better understanding of asset pricing patterns in financial markets, and the efforts are academically advocated. As a result, it can be used as a reference for better investment decisions and better incentives for asset managers (Zaremba \& Szyszka, 2016). Thus, intense efforts apparent among academia in exploring the topic.

According to Fama (1970), an efficient market is a market in which prices always fully reflect available information. Albeit previous evidence that the stock market is rational hence efficient, a substantial amount of studies have documented long-term historical anomalies in the stock market that appear to oppose the efficient market hypothesis (Aduda \& Muimi, 2011). Anomalies in stock returns are abnormalities in the behavior of stocks on the markets (Jilek, 2012). Considerable factors, such as technical, fundamental even behavioral factors, create market anomalies that affect the prices and volume of stocks traded in the markets. Schwert (2003) contends that anomalies indicate either market inefficiency (profit opportunities) or inadequacies in the underlying asset-pricing model. Basu (1978) and Jensen (2007) independently test the efficient market hypothesis, and both find that there were inadequacies. Many researchers dedicated their time to analyze some alternative grounds of the anomalies.

The answers are still inconclusive on a question like why stock returns in particular time are higher in than in other ones. Majority of researchers support the view that psychological effects are among the primary determinant (Jilek, 2012). Hence, the process of decision making in businesses is driven by managements' moods and feeling instead of relying on information available in the market which leads to market inefficiency (Barberis \& Thaler 2003).

Researches on market anomalies are well evident across nations (Siddiqui, 2009; Mabrouk \& Mohamed, 2013; Makino, 2016; Al-Taqheb, 2018). The studies looked at how the international stock market reacted to specific macroeconomic events occurring in a particular nation. Likewise, the euphoria of market anomaly research is also approaching countries with emerging economies like Indonesia. In fact, emerging markets are considered to be the tank of stock market anomalies (Zaremba \& Szyszka, 2016). For example, Suganda \& Sabbat (2014) revealed that dividend was considered as a wrong signal for the Indonesian capital market. Another study by Emrinaldi \& Susilowati (2015) alleged that there were no differences in stock value 
for the company with the different degree and scope of internet financial reporting disclosure. Majority of the available pieces of literature on event studies in Indonesia were focusing on companies' policy events such as mergers and acquisitions, stock split, earnings announcement, dividend announcement, and very few on religious events. The authors acknowledge some attempt to link between Islamic event to stock movement (Al-Hajieh, Redhead, \& Rogers, 2011; Ramezani, Pourahajan, \& Mardani, 2013; Atala, 2014). However, there is no specific investigation on the effect of Muslim street mobilization on the stock price movement.

The street rallies bring mixed feelings on the events such as the fear of the country's disintegration, economic disturbance as well as adverse social reactions. There was a threat of mutual distrust and disharmony among the different religious group's post events. Police and Armed Forces (TNI) leaders had continually alerted about the risks and accordingly deployed high-level security. Albeit the National Police and the Armed Forces had instructed their regional leaders to cooperate with local officials to discourage people from leaving their areas and join in the demonstration in Jakarta.

Based on the efficient market hypothesis theory, the author assumes that Muslim street mobilization is an event that may result in economic sentiment which may later become a significant transmission mechanism for stock market contagion and hence a potential source of causality (Al-Thaqeb, 2018). The role of economic sentiment as a determinant of stock returns offers a basis for applying herd behavior theories in the Indonesian capital market. A question arises whether the street movement is a form of political risks faced by investors in the capital market or not? This paper shall address the issue in the later section.

We chose the Indonesian capital markets for a few reasons. First, market anomalies were first discovered in a developed market and had yet to be measured in developing countries such as Indone- sia. Some past studies were evidencing the failure of the event in the most prominent anomalies in emerging markets (Al-Hajieh, Redhead, \& Rogers, 2011; Ramezani, Pourahajan, \& Mardani, 2013; Atala, 2014; Li et al., 2016). The result of our research may also confirm the way investors used available information for decision-making. Second, the impact of 'super-peaceful 411 and 212 rallies' on stock return has not yet been examined while the event affects Muslims behavior as the people majority in the country. Third, the stock market in Indonesia has been proliferating, regarding both market capitalization and the number of stocks. This indicates the growing importance of investors who look for portfolio diversification in the Indonesian stock market.

This study contributes to existing literature as the first to analyze the impact of the super peaceful rally on the pattern of stock price and trading volume in the Indonesian stock market as an emerging country. Examination of stock market anomalies in Indonesia enriches previous works by Pinheiro, \& Smith (2015), Green, Hand, \& Zang (2016), Grobys \& Heinonen, (2016), Igan, Pinheiro, \& Smith (2015), Zaremba, \& Szyszka (2016), and Zaremba \& Czapkiewcz (2017), although none of these studies focus on anomalies include East Asian Markets. The currently available literature merely discuss a few anomalies (Cakici, Fabozzi, \& Tan, 2013; Waszczuk, 2013). In the context of emerging markets, the broadest study ever conducted was by Li et al. (2016), who investigated 16 well-known predictive signals in multiple countries. Thus, the result of the survey can be used as a reference by investors on stock return behavior in a case of religious-based events, which we believe, are still lacking.

Summing up, by researching the above-discussed issues, our study aims to provide new insights into market anomalies in Indonesia, as well as outstanding results for both the academic community and market practitioners. 


\section{The Contagion Effect of Muslim Street Rallies on Stocks' Volatility: Is it a Political Risk for Investors?}

Wiwiek Rabiatul Adawiyah \& Bambang Agus Pramuka

\section{HYPOTHESES DEVELOPMENT}

The study used three main theories- the random walk theory, the efficient market hypothesis, and behavioral finance as the underlying assumption of the frameworks. The random walks theory suggest the absence of memory on changes in a series of stock price makes the history to be a meaningless predictor of the future stock price motion (Fama, 1965). The truth is successive price changes are independent. Therefore there is no serial correlation between the stock prices across times (Fama, 1970). The random walk notion implied that today's stock prices contain all the information occurring on that day, and the following day's prices will reflect only tomorrow's news. Therefore, today's prices changes are independent of the one that is occurring tomorrow. The impulsive nature of information leads to random and unpredictable prices changes.

These phenomena bring benefits to all sorts of investors. When data are fully reflected in the stock prices, even uninformed investors who invest in a diversified portfolio will earn a return as generous as that gained by the experts (Malkiel, 2003). Critiques on the random walk theory came to surface in the late $19^{\text {th }}$ century. The theory states price movements are not all random and the predictable components of investment do exist. Lo \& MacKinlay (1999) are among scholars who initiated against the random walk hypothesis. They argue that stock market prices do not follow random walks and financial markets are predictable to some degree.

The theory of Efficient Market Hypothesis (EMH) proposes that share prices encompass all vital information useful for decision makers and stockbrokers in the particular industry. The theory implies that none of the investors can systematically get a return above the market rate. In an efficient capital market, the stock prices response quickly to every available information thereby allowing the stock prices to react and adjust accordingly. Inves- tors cannot make profits on trading shares based on readily available information alone as the price movements cannot be solely predicted based on it. Instead, the stock prices movements rely on the future performance (read: profit) of firms. Based on this assumption, stock prices are among useful major economic indicators. Therefore, the dynamic relationship between stock prices and the macroeconomic indicator is a crucial benchmark in formulating the nation's macroeconomic policies (Maysami, Wee, \& Koon, 2004). Some past studies on EMH were inconclusive. Some academics allege that tests of the EMH have a significant deficiency, for example, Grossman \& Stiglitz (1980), Campbell, Lo, \& Mackinlay (1997), Lo (2004) and (2005), Al-Khazali \& Mirzaei (2017). Market efficiency is evolving due to changes in market factors such as the government political will, technological advances as stockbrokers' behaviors.

The event of Muslim street rallies in Indonesia is among market factors, which influence financial market efficiency. As the stock markets developed, investors understanding on the anomalies improve market efficiency which later leads to decline profitability patterns. When market anomalies symptoms are weakening or even disappearing because of the event, market practitioners are recommended to deliver the most. In light of the disappearance or weakening of the stock market anomalies, it becomes of highest importance for market practitioners to select the most promising strategies. Recent literatures revealed that markets' volatility occurring because of events such as the Asian financial crisis (Kim \& Shamsuddin, 2008; Lim, Luo, \& Kim, 2013), and the Global Financial Crisis (Kim, Lim, \& Shamsuddin, 2011; Smith, 2012), shall determine the degree of market efficiency. These events have substantial implications for the psychology of the market. Taking advantage of these recent developments, we seek to examine in this paper the market anomalies caused by the Muslim street mobilization. 
Behavioral finance is becoming popular at the beginning of the twentieth century, leaving the efficient market hypothesis less popular. A multidisciplinary approach to asset pricing integrating psychological and behavioral theories are mounting (Lishenga, 2011; Putri, Adawiyah, \& Pramuka, 2017). Behavioral finance theory proposes that a high level of uncertainty creates exploratory behavior of investors in financial decisions. The method uses a more simplified approach to study the commercial market. Specifically, behavioral finance has two building blocks: cognitive psychology and the limits to arbitrage. Cognitive refers to how people think. Shefrin \& Statman (2011) add that psychology includes aspirations, cognition, emotions, culture, and perceptions of fairness. People make systematic errors in the way that they think, they are overconfident, they rely heavily on recent experience, and making preferences that may lead to distortions.

An excellent question to start with is "why people behave the way they do?" The revolutionary work of psychologists in the 1980s and the subsequent psychological inquiry undertaken over the last three decades have laid useful insights on the complex ways in which the human mind operates. Past studies have pointed out the presence of pervasive, deep-seated, subconscious biases and heuristics behaviors that occur in rational decision-making. While these revelations have their origins in psychology, they hold such significant implications for the world of finance and economics.

The political movement shall influence the economic condition of a country with an emerging market (Gunay, 2016). The uncertain environment caused by political instability affects the risk-return profiles of stocks in the Indonesian capital market, and cause an increase in the required rate of return on current and future investments in the nation. In the long run, the subsequent decline in living standards puts more pressure on the political power.

There are several forms of financial risks face by investors such as market risks, credit risks, and operational risks. One of the most prominent risk categories in emerging market is political risks. The Indonesian capital market is relatively volatile towards all sorts of threats. Therefore, investors shall exhibit prudential actions when entering the market due to its destabilization. Increasing volatility in the capital market brings deadly effect to the economy that may lead to financial turbulence (AlKhazali \& Mirzaei, 2017). To mitigate further market deterioration, the government should impose stricter regulation as a form of direct intervention. To drive investors' perceptions about the political risk of a country, the government should have early warning systems to anticipate the contagious effect an event into the capital market. Technically investors' decision to hold or release their ownership of stocks does not depend on fundamental factors such as the financial performances of the firms. Beyond that investors react more to any political events. These types of operations are direct interventions, made by policy-makers, on the market economy. Based on the underlying theories presented earlier, the following hypotheses are proposed:

$\mathrm{H}_{1}$ : there was a significant difference in average abnormal return among the event date, before and after it

$\mathrm{H}_{2}$ : there was a significant difference between stock trading volume among the event date, before and after it

\section{METHODS}

This study analyzes two events of the peaceful rally on $4^{\text {th }}$ of November and $2^{\text {nd }}$ of December 2016. This event study investigates the market reaction towards a specific event. The tool of analysis used was one-way ANOVA which is a parametric test used to determine whether there are any statistically significant differences between the means of three or more independent groups (Hair et al., 2010). The three independent variables used in the study were seven days before $(t-1)$, and after $(t+1)$ the events as well as the time of events $(t)$ with the 


\section{The Contagion Effect of Muslim Street Rallies on Stocks' Volatility: Is it a Political Risk for Investors?}

Wiwiek Rabiatul Adawiyah \& Bambang Agus Pramuka

abnormal return and trade volume as dependent variables. One-way ANOVA requires researchers to surpass the underlying assumptions of normality test and homogeneity test. Normality test was used to determine whether the observed data are normally distributed or not. The homogeneity tests to ensure the entire groups, under study, must have the same variants. The analysis of homogeneity of variance was performed using the Levene test.

The population in this study was all stocks listed on the LQ45 index. The samples comprise all stocks listed in the LQ45 index for at least three years since 2014-2016 consecutively. The index reflects firms with large market capitalization and high liquidity levels, as well as outstanding fundamental performance. Firms use fundamental performance as a benchmark in distributing dividends and generating profits the information have a high level of market sensitivity.

The variables observed were the daily closing of share index and the stock trading volume seven days before and after the events. The market reaction toward the event was measured based on changes in the stock prices measured by the abnormal return. According to Bodie, Kane, \& Marcus (2006), the abnormal return measures return over and above what would be expected given the market conditions in a particular period. Actual return is the return that occurs in a particular time to which represents the differences between the prices of stocks at that moment relative to their previous prices. Real gain can be obtained from the daily stock prices of securities $i$ in period $t$ minus the daily stock price of securities $i$ in period $t-1$, divided by the daily stock price of securities $i$ in period $t-1$. It can be formulated as follows:

$R i_{t}=\frac{P i_{t}-P i_{t-1}}{P i_{t-1}}$

Where

$\mathrm{Ri}_{\mathrm{t}}$ : return of stock $\mathrm{i}$ on day $\mathrm{t}$

$\mathrm{Pi}_{\mathrm{t}}$ : price of stock $\mathrm{i}$ on day $\mathrm{t}$

$\mathrm{Pi}_{\mathrm{t}-\mathrm{z}}$ : price of stock $\mathrm{i}$ on day $\mathrm{t}-1$
Single factor model states that the actual returns diverge from expectation due to the macro event and firm-specific event. Single index model merely replaces the macro event with a broad market index. The model omits the risk-free rate. The model implies that the expected return on a security is linearly related to its beta (Ross, Westerfield, \& Jaffe, 2010) which can be measured as follows:

$$
E(\text { Rit })=\alpha i+\beta i R m t
$$

Where:

E (Rit) : expected return of stock $i$ on day $t$

Rmt : market return on day $t$

$\alpha \mathrm{i} \quad$ : the abnormal return offered by asset $\mathrm{i}$ (unexplained expected return)

$\beta i \quad$ : a constant that measure the expected change in Ri given a change in $\mathrm{Rm}$

Rmt : the rate of return on the market index

The $\alpha$ and $\beta$ coefficient were obtained from the calculation of time series regression equation between stock returns (Rit) with a related market return (Rmt). Trading volume activity measures the numbers of security trading take place for a given trading day. A high trading volume is an indicator of a high level of interest in security at its current price which reflects the strength of a market indicator. The method for determining trading volume is called volume counting.

\section{RESULTS}

Descriptive statistics were conducted to determine the difference in the average of abnormal return and trading volume activity as an instrument to calculate the return and liquidity level of the listed in the Indonesia Stock Exchange. The normality assumption for average abnormal return was not violated, but the average trading volume activity was infringed. The mean of each variable is presented in Table 1. 
From the descriptive statistics above for when the super peaceful rally took place on November $4^{\text {th }}, 2016$ revealed that the normal returns had mean of -0.0072 and a standard deviation of 0.1308 which is large indicating high sensitivity in the market. Similarly, the mean abnormal returns of 0.026 and a standard deviation of 0.1122 show high sensitivity.

The result for trading volume, as indicated in Table 2, revealed that the mean-rank of average trading volume activity seven days before the street rally on November $4^{\text {th }}, 2016$ was 34.48 which was above the volume during the event and slightly declining seven days after the event with a mean rank of 32.64. It can be assumed that the market reacted to the event.
From the descriptive statistics of abnormal return seven days before the second super peaceful rally on December $2^{\text {nd }}, 2016$ revealed that the normal returns had mean of -0.00053 and a standard deviation of 0.018 which is considered small, hence indicating low sensitivity in the market. Likewise, the mean abnormal returns seven days after the peaceful rally were -0.00341 and a standard deviation of 0.017 show a low sensitivity.

The result for trading volume, as indicated in Table 4, revealed that the mean-rank of average trading volume activity seven days before the street rally on the second event was 26.48 which was below the volume during the event and slightly increasing seven days after the event with a mean rank

Table 1. The Average Abnormal Return in 411 Event

\begin{tabular}{llcccc}
\hline & N & Minimum & Maximum & Mean & SD \\
\hline ASRB_4NOV & 29 & -.04 & .03 & -.0072 & .01308 \\
ASRA_4NOV & 29 & -.01 & .04 & .0026 & .01122 \\
Valid N (listwise) & 29 & & & & \\
\hline
\end{tabular}

Table 2. The Average Trading Volume in 411 Event

\begin{tabular}{llc}
\hline \multicolumn{1}{c}{ Events } & N & Mean Rank \\
\hline Seven days before & 29 & 34.48 \\
November 4th, 2016 & 29 & 21.80 \\
Seven days after & 29 & 32.64 \\
\hline
\end{tabular}

Table 3. The Average Abnormal Return in 212 Event

\begin{tabular}{|c|c|c|c|c|c|}
\hline & $\mathbf{N}$ & Minimum & Maximum & Mean & SD \\
\hline ASRB_2DES & 29 & -0.02771 & 0.03819 & -0.00053 & 0.018 \\
\hline ASRA_2DES & 29 & -0.03645 & 0.02821 & -0.00341 & 0.017 \\
\hline Valid N (listwise) & 29 & & & & \\
\hline
\end{tabular}

Table 4. The Average Trading Volume of Stocks in 212 Event

\begin{tabular}{|c|c|c|}
\hline Events & $\mathbf{N}$ & Mean Rank \\
\hline Seven days before & 29 & 26.48 \\
\hline December 2nd, 2016 & 29 & 32.10 \\
\hline Seven days after & 29 & 28.58 \\
\hline
\end{tabular}




\section{The Contagion Effect of Muslim Street Rallies on Stocks' Volatility: Is it a Political Risk for Investors? \\ Wiwiek Rabiatul Adawiyah \& Bambang Agus Pramuka}

of 32.64. It can be assumed that the market reacted to the event.

Before proceeding to one-way ANOVA, the authors tested the normality and homogeneity of all data. The normality tests using KolmogorovSmirnov indicated that Asymptotic Significant value of the indicator average abnormal return and volume for three days before, during and after both events were respectively higher than the alpha value of 0.05 . This indicates that the data are normally distributed.

The second requirement of ANOVA that the data must have the same variants (homogeneous). One statistical method used to test the assumption was the Levene test. The result indicated that the homogeneity assumptions were not violated, as the significant value was higher than alpha ( $p>0.05)$.

As both requirements were fulfilled, the authors proceed to next analysis using one-way ANOVA. One-way ANOVA is a tool of analysis which is used to determine whether there are any significant differences between the mean of independent variable or not. The first hypothesis proposed that there be a significant difference in average abnormal return among the event date, before and after it. Table 5 presented the result of the analysis.

Table 5. One-Way ANOVA Test on the Average Abnormal Return

\begin{tabular}{ccc}
\hline Value & \multicolumn{2}{c}{ Events } \\
\hline & November $4^{\text {th }}$ & December 2nd \\
\cline { 2 - 3 } Sig. & 0.030 & 0.315 \\
\hline
\end{tabular}

As indicated in the Table 5 there are significant differences on stocks average abnormal return before and after the event on November 4th, 2016, because the significant value is less than alpha $(\alpha)$. However, the result is contradictory for the $2^{\text {nd }}$ of December events. The most plausible explanation is related to the timing of the events. The first event raises excessive anxiety among investors which leads to aggressive behaviors to secure their investments.
Unlike the first event, there were no significant differences in the stock return before and after the second event. The second event occurs one month after the first event.

The second hypothesis proposed that there be a significant difference between stock trading volume among the event date, before, and after it. Table 6 showed the result of one way ANOVA on stock trading volume.

Table 6. One-way ANOVA Test on Stock Trading Volume

\begin{tabular}{ccc}
\hline Value & \multicolumn{2}{c}{ Events } \\
\hline Sig. & ${\text { November } 4^{\text {th }}}^{\text {ny }}$ & December 2 $^{\text {nd }}$ \\
\cline { 2 - 3 } & 0.013 & 0.309 \\
\hline
\end{tabular}

As indicated in Table 6, there is a significant difference on the stock trading volume during the event on November $4^{\text {th }}$, with the volume before and after the event, The significant value was less than alpha $(0.013<0.05$, sig. $<\alpha)$ means that the null hypothesis is rejected. Because the test shows that there is a significant difference in average trading volume activity during the event with that before the events, the authors conducted further analysis to identify the differences correctly. Post HOC test aimed to identify the gaps correctly.

The Games-Howell multiple comparisons for the mean average trading volume activity on street rally event on November $4^{\text {th }}, 2016$ indicated that the significant mean differences are flagged with an asterisk $\left({ }^{*}\right)$ and the mean difference would be significant if the value is less than the alpha value of 0.05 . The second line tells us that the mean score at the time of the event was 0.00021 which below that of $\mathrm{t}-$ 1 . The significant value is less than alpha $(0.024<0.05$, sig. $<\alpha)$ confirmed that a significant difference existed between the two means. The multiple comparisons indicated only one significant comparison emerge while others were not significant (sig. $>\alpha$ ).

\section{DISCUSSION}

The first event raises excessive anxiety among investors which leads to aggressive behaviors to 
secure their investments. These findings support previous views that anomalies in stock returns are abnormalities in the behavior of stocks on the markets (Jilek, 2012). Substantial factors, such as technical, fundamental even behavioral factors, create market anomalies. Market anomaly affects the prices and volume of stocks traded in the markets. Efficient markets do not allow investors to earn aboveaverage returns without accepting above-average risks (Malkiel, 2003).

According to Fama (1970), a market in which prices always fully reflected available information is efficient. As such when information arises, it shall spread immensely fast, therefore incorporated into the prices of securities without further delay. Hence, the majority of researchers support the view that psychological effects are among the primary determinant (Jilek 2012). Accordingly, the process of decision making in businesses is driven by managements' moods and feeling instead of relying on information available in the market which leads to market inefficiency (Barberis \& Thaler, 2003).

Unlike the first event, there were no significant differences in the stock return before and after the second event. The second event occurs one month after the first event. The fact that the first event did not cause disturbances in the national economy made investors act conservatively. These findings work in line with the random walk theory effect. The theory suggests that a series of stock price changes have no memory of the past events, therefore, the sequence unable to predict the future in any meaningful way (Fama, 1965). In statistical terms, successive price changes are independent. Consequently, there must be no serial correlation between the prices at different times (Fama, 1970). Some past studies on various emerging markets to test if indeed stock prices follow a random walk model revealed that to some extent stock prices are predictable. This finding suggested that market inefficiencies existed. Other similar works conducted in various countries include Hong Kong (Jarreth, 2008), China (Ali, Darrat, \& Zhong 2000), Korea (Jarrett, 2009) and Kenya (Muthama \& Mutothya, 2013).

The result support the second hypothesis which proposed that there was a significant difference between stock trading volume among the event date, before and after it. This finding supports previous work suggested that Islamic event had a significant effect on trade volume and stock price (AlHajieh, Redhead, \& Rogers, 2011; Ramezani, Pourahajan, \& Mardani, 2013; Atala, 2015). It is noteworthy that the difference was significant on average trading volume and average abnormal return on the first event, but it was not significant in the following event. The fact that the first event resulted in little or even relatively no political disturbance in any forms have led to favorable trust among investors on similar events in the future. As a result, there was a tendency to neglect negative economic sentiments during the second events.

Table 7. Post HOC Test for Average Volume on November $4^{\text {th }}, 2016$

\begin{tabular}{|c|c|c|c|c|c|c|c|}
\hline & \multirow[b]{2}{*}{ Event A } & \multirow[b]{2}{*}{ Event B } & \multirow[b]{2}{*}{$\begin{array}{l}\text { Mean Difference } \\
\text { (A-B) }\end{array}$} & \multirow[b]{2}{*}{ Std. Error } & \multirow[b]{2}{*}{ Sig. } & \multicolumn{2}{|c|}{$95 \%$ CI } \\
\hline & & & & & & $\begin{array}{l}\text { Lower } \\
\text { Bound }\end{array}$ & Upper Bound \\
\hline Games- & $t-1$ & $\mathrm{~T}$ & $0.00021^{*}$ & .000 & .024 & .00 & .00 \\
\hline \multirow{5}{*}{ Howell } & & $t+1$ & .000 & .000 & .925 & .00 & .00 \\
\hline & $t$ & $\mathrm{t}-1$ & $0.00021^{*}$ & .000 & .024 & .00 & .00 \\
\hline & & $t+1$ & .000 & .000 & .072 & .00 & .00 \\
\hline & $t+1$ & $\mathrm{t}-1$ & .000 & .000 & .925 & .00 & .00 \\
\hline & & $\mathrm{T}$ & .000 & .000 & .072 & .00 & .00 \\
\hline
\end{tabular}

*. The mean difference is significant at the 0.05 level 


\section{The Contagion Effect of Muslim Street Rallies on Stocks' Volatility: Is it a Political Risk for Investors? \\ Wiwiek Rabiatul Adawiyah \& Bambang Agus Pramuka}

\section{CONCLUSION AND SUGGESTIONS}

\section{Conclusion}

This paper tested the semi-strong form of an efficient market hypothesis, which confirmed that published information on the street rallies event could not be used to predict future stock prices and trading volume. The vast majority of people living in Indonesia are Muslim. Therefore, any religious events would assume to affect investors' behaviors. The fact that significant difference only occurred in the first event implies that religious activities do not always create political economics disturbances. Those fund managers who exhibit outstanding performance during and after the events were no more than just pure randomness. The tranquil behavior of Muslim protestors in the first event had given a positive signal to investors which makes them calmer when the following event took place. In a nutshell, the Muslim street rallies is not a political risk that would bring economic sentiment in the capital market. The fact that the street rallies did not lead to negative sentiments implies that investors should chill out and do not overreacting if a similar event occurs in the future, as the event did not affect the stock price movement in the second events. Investors should still use available information for decision-making purposes. Investors are advised to use an average weighting method for different sort of information received to determine their priority of importance. In the meantime, the government should provide a favorable investment climate to attract not just local investors but also foreign investors. To date, the stock market in Indonesia is proliferating concerning capitalization and the number of stocks traded.

\section{Suggestions}

This study is not without limitations. First, short observation period, before and after the events, may limit the generalizability of the study in other contexts. Data drawn from similar events in other country are required to verify the theoretical advances offered here. Second, the methodology used in the study is simple; the future study may consider extending the method using nonparametric statistical analysis. This research can be extended in four ways. First, enlarge the dataset to incorporate more similar event, money market, and commodity data, and increase the data frequency to check the robustness of the current conclusion. Second, include more variables to the tests impact of the events. Third, extend the test window to 30 days or even longer to detect the effect. Last, the future study may consider the adoption of an event study method instead in testing the future similar events.

\section{REFERENCES}

Aduda, J., \& Muimi P. (2011). Test for investor rationality for companies listed at the Nairobi Stock Exchange. Journal of Modern Accounting and Auditing, 7(8), 827-840. Retrieved from: http:/ / erepository.uonbi.ac.ke/ handle/11295/13969

Al-Hajieh, H., Redhead, K., \& Rodgers, T. (2011). Investor sentiment and calendar anomaly effects: A case study of the impact of
Ramadan on Islamic Middle Eastern markets. Research in International Business and Finance, 25(3), 345-356. https://doi. org/10.1016/j.ribaf.2011. 03.004

Ali, F., Darrat, A. F., \& Zhong M. (2000). On testing the Random-Walk Hypothesis: A Model-Comparison Approach. The Financial Review, 35(1), 105-124. https://doi.org/10.1111/ j.1540-6288.2000.tb01423.x
Al-Khazali, O., \& Mirzaei, A. (2017). Stock market anomalies, market efficiency, and the adaptive market hypothesis: evidence from Islamic stock indices. Journal of International Financial Markets, Institutions, and Money, 52, 190-208. https://doi.org/ 10.1016/j.intfin.2017.10.001

Al-Thaqeb, S. (2018). Do international markets overreact? Event study: International market reaction to U.S. local news events. Research 
in International Business and Finance, 44,369-385.https:/ /doi.org/ 10.1016/j.ribaf.2017.07.106

Atala, M. M. (2014). The effect of Muslim holidays on stock returns of listed companies at the Nairobi Securities Exchange. University of Nairobi.

Basu, S. (1978). Investment performance of common stocks in relation to their price-earnings ratio: A test of the efficient market hypothesis. The Journal of Finance, 32(3), 663. https:// doi.org/10.1111/j.15406261.1977.tb01979.x

Barberis, N., \& Thaler, R. (2003). A survey of behavioral finance. Handbook of the Economics of Finance, 1(2), 1053-1128. https:/ /doi.org/10.3386/w9222

Bodie, Z., Kane, A., \& Marcus, A. (2006). Investments. First Edition. New York: McGraw-Hill/ Irwin.

Cakici, N., Fabozzi, F. J., \& Tan, S. (2013). Size, value, and momentum in emerging market stock returns. Emerging Markets Review, 16, 46-65. https:// doi.org/10.1016/j.ememar. 2013.03.001

Campbell, J. Y., Lo, A. W., \& MacKinlay, A. C. (1997). The Econometrics of Financial Markets. Princeton: Princeton University Press.

Emrinaldi, N. D. P., \& Susilowati, E. (2015). Perbandingan tingkat dan ruang lingkup pengungkapan pelaporan keuangan basis internet terhadap harga saham. Jurnal Keuangan dan Perbankan, 19(2), 252-262. Retrieved from: http:// jurnal.unmer.ac.id/index. php/jkdp/article/view/847
Fama, E. F. (1965). The behavior of stock-market prices. The Journal of Business, 38(1), 34-105. https://doi.org/10.1086/ 294743

Fama, E. F. (1970). Efficient capital markets: A review of theory and empirical work. Journal of Finance, 25(2), 383. https:// doi.org/10.1111/j.15406261.1970.tb00518.x

Green, J., Hand, J. R. M., \& Zhang, F. (2016). The characteristics that provide independent information about average U.S. monthly stock returns. Retrieved from SSRN: http://dx.doi.org/10.2139/ ssrn. 2262374

Grobys, K., \& Heinonen, J. P. (2016). Is there a credit risk anomaly in FX markets? Finance Research Letters, 18, 1-6. http://dx.doi. org/10.1016/j.frl.2016.03.011

Grossman, S. J., \& Stiglitz, J. E. (1980). On the impossibility of informationally efficient market. The American Economic Review, 70(3), 393-408. https:// doi.org/10.7916/D8765R99

Gunay, S. (2016). Is political risk still an issue for Turkish stock market? Borsa_Istanbul Review, 16(1), 21-31. https://doi.org/ 10.1016/j.bir.2016.01.003

Hair, J. F., Black, W. C., Babin, B. J., \& Anderson, R. E. (2010). Multivariate Data Analysis. 7th Edition. Upper Saddle River, New Jersey: Prentice Hall.

Igan, D., Pinheiro, M., \& Smith, J. (2015). A study of a market anomaly: "White Men Can't Jump," but would you bet on it? Journal of Economic Behavior and Organization, 113, 13-25. https://doi.org/10.1016/ j.jebo.2015.02.005
Jarreth, J. E. (2008). Random walk, capital market efficiency, and predicting stock returns for Hong Kong Exchanges and clearing limited. Management Research News, 31(2), 142-148. https://doi.org/10.1108/ 01409170810846858

Jensen, M. C. (2007). Some anomalous evidence regarding market efficiency. Journal of Financial Economics, 6(2), 95-101. https:// doi.org/10.1016/0304405X(78)90025-9

Jilek, L. (2012). Analysis of stock market anomalies: US crosssectoral comparison. Paper (Unpublished). Charles University in Prague Faculty of Social Sciences Institute of Economic Studies.

Kim, J. H., \& Shamsuddin, A. (2008). Are Asian stock markets efficient? Evidence from new multiple variance ratio tests. Journal of Empirical Finance, 15(3), 518-532. https://doi.org/ 10.1016/j.jempfin.2007.07.001

Kim, J. H., Lim, K. P., \& Shamsuddin, A. (2011). Stock return predictability and the adaptive markets hypothesis: Evidence from century-long U.S. data. Journal of Empirical Finance, 18(5), 868879. https://doi.org/10.1016/ j.jempfin.2011.08.002

Lim, K. P., Luo, W., \& Kim, J. H. (2013). Are US stock index returns predictable? Evidence from automatic autocorrelation-based tests. Applied Economics, 45(8), 953-962. https://doi.org/ 10.1080/00036846.2011.613782

Li, P. M., Zhang, Q., Cai, C.X., \& Keasey, K. (2016). Understanding asset pricing anomalies across the globe: The role of news watchers. Retrieved from SSRN: 


\section{The Contagion Effect of Muslim Street Rallies on Stocks' Volatility: Is it a Political Risk for Investors?}

Wiwiek Rabiatul Adawiyah \& Bambang Agus Pramuka

http://dx.doi.org/10.2139/ ssrn.2839799

Lishenga, J. L. (2011). The profitability of momentum trading strategies in emerging markets: evidence from Nairobi Stock exchange. Paper (Unpublished). MBA project, University of Nairobi.

Lo, A. W. (2004). The adaptive markets hypothesis. Journal of Portfolio Management, 30, 15-29. https:// doi.org/10.3905/ jpm.2004.442611

Lo, A. W. (2005). Reconciling efficient markets with behavioral finance: The adaptive market hypothesis. Journal of Investment Consulting, 7, 21-44. Retrieved from: https://papers.ssrn. com/sol3/papers.cfm? abstract_id $=728864$

Lo, A. J., \& Mackinlay A. C. (1999). A Non-random Walk Down Wall Street. New Jersey: Princeton University Press.

Mabrouk,H. B., \& Mohamed, F. (2013). Herding during market upturns and downturns: International evidence. IUP Journal of Applied Finance, 19(2), 5-26. Retrieved from: https://papers. ssrn.com/sol3/papers.cfm? abstract_id $=2260188$

Makino, R. (2016). Stock market responses to chemical accidents in Japan: An event study. Journal of Loss Prevention in the Process Industries, 44, 453-458. https://doi.org/10.1016/ j.jlp.2016.10.019

Malkiel, G. M. (2003). The efficient market hypothesis and its critics. Journal of Economic Perspectives, 17(1), 59-82. https:// doi.org/10.1257/ 08953300 3321164958

Maysami, R. C., Wee, L. S., \& Koon, K. T. (2004). Co-movement among sectoral stock market indices and cointegration among dually listed companies. Jurnal Pengurusan, 23,33-52. Retrieved from: http://ejournal.ukm.my/ pengurusan/article/view/ 1245

Muthama, N., \& Mutothya, N. (2013). An empirical investigation of the random walk hypothesis of stock prices on the Nairobi Stock Exchange. European Journal of Accounting Auditing and Finance Research, 1(4), 33-59.

Putri, N. K., Adawiyah, W. R., \& Pramuka, B. A. (2017). Independence of audit ethical decision making process: A case of Indonesia. DLSU Business \& Economics Review, 26(2), 115-124. Retrieved from: https:// ejournals.ph/article.php?id= 11289

Ramezani, A., Pourahajan, A., \& Mardani, H. (2013). Studying impact of Ramadan on Stock Exchange Index: Case of Iran. World of Sciences Journal, 1(12), 46-54.

Ross. A. W., Westerfield, R.W., \& Jaffe, W. (2010). Return and Risk- The Capital Asset Pricing Model. Corporate Finance. New York: McGraw-Hill/Irwin.

Schwert, G. W. (2003). Anomalies and market efficiency. In: Constantinides, G. M., Harris, M., Stulz, R. (Eds.). Handbook of the Economics of Finance, 937-972.

Shefrin, H., \& Statman, M. (2011). Behavioral finance in the financial crisis: Market efficiency, minsky, and keynes. Paper (Unpublished). Santa Clara University.

Smith, G. (2012). The changing and relative efficiency of European emerging stock markets. The European Journal of Finance, 18(8), 689-708. https:// doi.org/10.1080/1351847X. 2011.628682

Siddiqui, S. (2009). Stock markets integration: Examining linkages between selected world markets. The Journal of Business Perspective, 13(1), 19-30. https:// doi.org/10.1177/0972262909 01300103

Suganda, T. R., \& Sabbat, E. (2014). Sinyal profitabilitas dan reaksi pasar modal terkait peningkatan dividen saat laba meningkat. Jurnal Keuangan dan Perbankan, 18(3), 335-344. Retrieved from: http://jurnal .unmer.ac.id/index.php/ jkdp/article/view/813

Waszczuk, A. (2013). A risk-based explanation of return patterns-Evidence from the Polish stock market. Emerging Markets Review, 15, 186-210. https://doi.org/10.1016/ j.ememar.2012.12.002

Zaremba, A., \& Czapkiewcz, A. (2017). Digesting anomalies in emerging European markets: A comparison of factor pricing models. Emerging Markets Review, 31, 1-15. https://doi.org/ 10.1016/j.ememar.2016.12.002

Zaremba, A., \& Szyszka, A., (2016), Is there momentum in equity anomalies? Evidence from the polish emerging market. Research in International Business and Finance, 38, 546-564. https:/ /doi.org/10.1016/j.ribaf. 2016.07.004 